Situs Jurnal : $\underline{\text { http://ejournal.stiepancasetia.ac.id/index.php/iieb }}$

Jilid 6 Nomor 1 Maret 2020

Hal $74-83$

\title{
HUBUNGAN KUALITAS PELAYANAN TERHADAP KEPUASAN MASYARAKAT DI KECAMATAN BANJARMASIN BARAT KOTA BANJARMASIN
}

\section{Junaidy, Murdiansyah Herman, Sugiannor}

Abstrak: Kualitas pelayanan ini menekankan pada orientasi pemenuhan kepuasan masyarakat secara umum di wilayah Kecamatan Banjarmasin Barat Kota Banjarmasin. Kualitas pelayanan menjadi fokus utama dalam upaya mencari hubungan terhadap kepuasan masyarakat. penelitian ini menggunakan pendekatan kuantitatif deskriptif dengan prosedur pengumpulan data survei. Lokasi penelitian dilakukan di Kantor Kecamatan Banjarmasin Barat. Skala pengukuran yang digunakan adalah Skala Linkert. Metode penentuan jumlah sampel menggunakan Metode Probability Sampling. Berdasarkan hasil penelitian dan pembahasan terhadap data yang ada, Kualitas Pelayanan tidak Tersebar Disemua tingkat kategori Dari hasil hitungan Chi squaere Goodness Of Fit dengan Chi Square $x^{2}$ hitung yaitu 59,750 , dan dengan nilai probalitasnya 0.000 dengan perbandingan tabel hitung df 6 dengan taraf signifikasi 5\% yaitu 12,592, Jadi $\mathrm{x}^{2}$ hitung 59,750 > $\mathrm{x}^{2}$ 12,592. Kepuasan Masyarakat tidak Tersebar Disemua tingkat kategori dengan Chi Square $x^{2}$ hitung yaitu 19,000, dan dengan nilai tingkat kategori yaitu 0.025. Dengan perbandingan tabel hitung df 9 dengan taraf signifikasi 5\% yaitu 19,000, Jadi $\mathrm{x}^{2}$ hitung 19,000 > $\mathrm{x}^{2}$ 16,919. Hubungan Kualitas Pelayanan dengan tingkat kepuasan $(X$ hitung denagan nilai 0,204 > 0,05) dengan kesimpulan Terdapat hubungan antara kualitas pelayanan dengan kepuasan masyarakat.

Kata kunci : Kualitas Pelayanan Dan Kepuasan Masyarakat.

\section{Latar Belakang}

Dalam pembukaan Undang-undang Dasar 1945 alenia ke empat secara tegas dinyatakan bahwa tugas Pemerintah Negara Kesatuan Republik Inonesia adalah melindungi segenap bangsa indonesia dan seluruh tumpah darah indonesia, memajukan kesejahteraan umum, mencerdasakan kehidupan bangsa dan ikut serta melaksanakan ketertiban dunia, perdamaian abadi dan keadilan sosial. Untuk dapat melaksanakan tugas umum tersebut dengan baik, maka Aparatur negara perlu dibekali kemampuan untuk melayani masyarakat.

Pelayanan publik merupakan salah satu tugas penting yang tidak dapat diabaikan oleh pemerintah daerah, sebab pelayanan publik meruapakan komponen yang selalu berhubungan dengan birokrasi pemerintah, mengingat tugas sebagai penyedia Pelayanan Publik yang melayani setiap masyarakat. Administrasi Publik atau penyelenggara pelayanan mempunyai peranan penting untuk menyediakan layanan Publik bagi semua penduduknya sesuai yang telah ditetapkan Undang-Undang. Undang-Undang 25 Tahun 2009 tentang Pelayanan Publik pasal 1 menyebutkan bahwa "Pelayanan publik adalah kegiatan atau rangkaian kegiatan dalam rangka kebutuhan pelayanan sesuai dengan peraturan perundang-undangan bagi setiap warga negara dan penduduk atas barang, jasa dan/atau administratif yang disediakan oleh penyelenggara pelayanan publik". Pelayanan Publik merupakan suatu usaha yang dilakukan kelompok atau seseorang birokrasi untuk memberikan bantuan atau pelayanan kepada masyarakat dalam rangka mencapai suatu 
tujuan tertentu. Salah satu dari pelaksanaan Pelayanan Publik yaitu administrasi kependudukan yang berada di suatu pemerintahan atau tingkat kabupaten.

Berdasarkan Kebijakan Daerah sebagai peran Aparatur Negara yang ditetapkan Pemerintah dalam Undang Undang No 23 tahun 2014 tentang pemerintah Daerah, yakni sebagai aparat birokrasi pemerintahan di daerah berhak mengelola dan menyelenggarakan Pelayanan Publik yang lebih peduli dengan kebutuhan masyarakat Daerahnya masing masing demi kesejahteraan rakyat. Terdapat konsep yang mendasar dalam hal mengelola urusan yang mengatur pemerintah lokal yakni adanya upaya sendiri berdasarkan pada aspirasi masyarakat daerah.

Otonomi daerah bermakna kemauan masyarakat lokal untuk memecahkan berbagai macam masalah masyarakat setempat demi tercapainya kesejahteraan masyarakat itu sendiri. Untuk mengejar target ketercapaian kesejahteraan masyarakat lokal/daerah yang semakin komplek, mau tidak mau pemerintah daerah harus memperbaiki dan meningkatkan kualitas pelayanan publik. Disini Otonomi daerah adalah merupakan hak, wewenang, dan kewajiban daerah otonom untuk mengatur dan mengurus sendiri urusan pemerintahan dan kepentingan masyarakat setempat sesuai dengan peraturan perundangundangan. Undang-undang yang mengatur pelaksanaan otonomi daerah di Indonesia adalah UUD 1945 Pasal 18 Ayat 1-7, 18A Ayat 1 dan 2, serta 18B ayat 1 dan 2. Otonomi daerah diberlakukan di Indonesia melalui UU Nomor 23 Tahun 1999 tentang Pemerintahan Daerah. Otonomi daerah dilaksanakan dalam rangka memperbaiki serta mengusahakan kesejahteraan rakyat. Otonomi daerah memiliki tujuan peningkatan pelayanan masyarakat yang semakin baik serta pengembangan kehidupan demokrasi di Indonesia.

Berbicara tentang pelayanan publik, sesuai dengan Pasal 1 Ayat (1) UndangUndang Nomor 25 Tahun 2009 Tentang Pelayanan Publik dinyatakan bahwa Pelayanan Publik merupakan kegiatan atau rangkaian dalam rangka pemenuhan kebutuhan pelayanan sesuai dengan peraturan perundang-undangan bagi setiap warga negara dan penduduk atas barang, jasa, dan/atau pelayanan administratif yang disediakan penyelenggara pelayanan publik. Berdasarkan pengertian tersebut, kegiatan pelayanan publik telah diatur pemenuhannya berdasarkan regulasi yang dibuat oleh pemerintah dengan tujuan utamanya untuk memenuhi kebutuhan dasar dan kesejahteraan masyarakat.

Penyelenggara Pelayanan Publik (M. Ridha, 2019) yang dimaksud disini adalah setiap institusi penyelenggara negara, korporasi, lembaga independen yang dibentuk berdasarkan Undang-Undang untuk kegiatan pelayanan publik, dan badan hukum lain yang dibentuk semata-mata untuk kegiatan pelayanan publik. Sedangkan Pelaksana Pelayanan Publik (M. Ridha, 2019)yang selanjutnya disebut Pelaksana adalah pejabat, pegawai, petugas, dan setiap orang yang bekerja di dalam organisasi penyelenggara yang bertugas melaksanakan tindakan atau serangkaian tindakan pelayanan publik.

Instansi pemerintah daerah seperti kecamatan merupakan salah satu contoh instansi pemerintah yang melaksanakan pelayanan publik. Kantor kecamatan sebagai lokomitof penyuedia jasa layanan publik ditingkat kecamatan mempunyai tugas pokok sebagai pembantu bupati yang dalam hal ini pemerintah daerah dalam penyelenggaraan pemerintahan, pembangunan dan kemasyarakatan dalam wilayah kecamatan serta meingkatkan efektivitas pelayanan publik dalam rangka Good Governance yaitu penyelenggaraan pemerintahan yang baik serta peningkatan kualitas pelayanan dalam bentuk jasa atau perizinan melalui transparansi dan standarisasi pelayanan. Adapun tugas lain dari kecamatan yaitu melayani dalam hal pembuatan Kartu tanda penduduk (KTP), akta kelahiran, surat nikah, sertifikat tanah, izin mendirikan bangunan (IMB) Keterangan Pindah, Pertanahan, ijin tebang kayu rakyat, surat keterangan catatan kepolisisan (SKCK), izin keramaian, legalisasi surat-surat dan program keluarga harapan. 
Pelayanan yang baik kepada masyarakat harus didukung oleh pegawai-pegawai yang handal, berkompeten dan mampu memahami serta dapat melaksanakan tugas pokok dan fungsinya sesuai dengan bidang tanggung jawab yang dibebankan kepadanya. Sekain itu, mereka tentu harus memiliki komitmen dan tanggung jawab moral terhadap masyarakat. Masyarakat tentunya ingin mendapatkan kualitas pelayanan yang baik dari pemerintah. Pelayanan yang berkualitas atau yang biasa disebut dengan pelayanan prima merupakan pelayanan terbaik yang memenuhi standar kualitas pelayanan.

Berdasarkan pra observasi yang penulis lakukan di Kantor Kecamatan Banjarmasin Barat Kota Banjarmasin, penulis menemukan masalah terkait pelayanan publik terkait dalam bidang administrasi kependudukan, ketiadaan petugas diloket pelayanan, keramahan petugas, maupun terkait dengan sarana dan prasarana umum. Masalah administrasi kependudukan seperti pembuatan KTP temuan permasalahan awal yang penulis temukan berupa ketidak sesuaian waktu/proses pembuatanya dari standar waktu tiga hari selesai membutuhkan waktu lebih dari itu, ketiadaan petugas diloket pelayanan mengakibatkan penguna layanan menunggu lebih lama dan menyebabkan petugas lain untuk melayanani diluar tugas pokok dan fungsinya, terkait ketidak ramahan petugas terlihat ketika pegawai yang tidak memberikan senyum kepada pengguna layanan, petugas yang mengobrol dengan petugas lain maupun membicarakan suatu masalah yang sama sekali tidak ada kaitannya dengan pekerjaan yang dihadapi sehingga masyarakat pengguna layanan yang menerima layanan tidak terlayani dengan baik. Selain itu penulis juga menemukan adanya respon pegawai yang tidak tanggap dengan masyarakat yang ingin melakukan pelayanan dan belum mengerti mengenai prosedur pelayanan. Sikap tidak tanggap sangat menggangu kualitas pelayanan yang dirasakan oleh masyarakat yang dapatang dan ingin mendapatkan pelayanan dengan baik. Dalam memperhatikan latar belakang diatas maka perlu dilakukan penelitian yang berkaitan dengan Hubungan Kualitas pelayanan terhadap Kepuasan Masyarakat di Kecamatan Banjarmasin Barat Kota Banjarmasin.

Penelitian ini bertujuan untuk mengetahui kualitas pelayanan yang diberikan oleh Kecamatan Banjarmasin Barat, Kepuasan Masyarakat terhadap pelayanan yang diberikan serta untuk mengetahui apakah terdapat hubungan antara kualitas pelayanan dan kepuasan masyarakat di Kecamatan banjarmasin barat. Hasil penelitian yang diperoleh diharapkan akan dijadikan dasar literasi bagi pengambil kebijakan untuk keperluan evaluasi dan penentuan program maupun kebijakan berikutnya.

\section{Kajian Literatur}

Pelayanan adalah merupakan proses pemenuhan kebutuhan melalui aktivitas orang lain, dan pada dasarnya setiap manusia membutuhkan pelayanan bahkan dapat dikatakan bahwa pelayanan tidak bisa dipisahkan dengan kehidupan. Pelayanan merupakan proses tolong-menolong, menyediakan segala apa yang diperlukan orang lain. Kegiatan pelayanan yang diberikan kepada masyarakat merapakan salah satu tugas dan fungsi administrasi.

Moenir (Dalam Aswin, A 2015) mengatakan bahwa, "pelayanan adalah proses pemenuhan kebutuhan melalui aktivitas orang lain secara langsung”. Sedangkan menurut Supriyanto dan Sugiyanti (2011) "pelayanan adalah upaya untuk membantu menyiapkan, menyediakan, atau mengurus keperluan orang lain.

Mauludin (2010: 67) mengemukakan bahwa kualitas pelayanan adalah seberapa jauh perbedaan antara kenyataan dan harapan pelanggan atas langganan yang mereka terima atau peroleh. Menurut Kotler (2012:49) mengemukakan bahwa kualitas adalah keseluruhan ciri serta sifat dari suatu produk atau pelayanan yang berpengaruh pada kemampuannya untuk memuaskan kebutuhan yang dinyatakan atau tersirat. 
Zeithaml, Berry dan Parasuratman (2009) menyatakan bahwa service quality dapat didefinisikan sebagai: "Seberapa jauh perbedaan antara kenyataan dan harapan pelanggan atas pelayanan yang mereka terima/peroleh." Harapan para pelanggan pada dasarnya sama dengan layanan seperti apakah seharusnya diberikan oleh perusahaan kepada pelanggan. Harapan para pelanggan ini didasarkan pada informasi dari mulut ke mulut, kebutuhan pribadi, pengalaman di masa lampau, dan komunikasi eksternal (iklan dan berbagai bentuk promosi perusahaan lainnya). Zeitham, Berry dan Parasuratman (2009) telah melakukan penelitian terhadap beberapa jenis jasa, dan berhasil mengidentifikasi dimensi karakteristik yang digunakan oleh para pelanggan dalam mengevaluasi kualitas pelayanan yang prima.

Menurut Zeithaml dkk dalam Hardiansyah (2017 : 95) untuk mengetahui kualitas pelayanan yang dirasakan secara nyata oleh konsumen, ada indikator ukuran kepuasan konsumen yang terletak pada 5 dimensi kualitas pelayanan menurut apa yang dikatakan konsumen. Kelima dimensi servqual itu mencakup beberapa sub dimensi sebagai berikut :

a. Tangibles / Bukti langsung (kualitas pelayanan yang berupa sarana fisik perkantoran, komputerisasi administrasi, ruang tunggu dan tempat informasi). Dimensi ini berkaitan dengan kemodernan peralatan yang digunakan, daya tarik fasilitas yang digunakan, kerapian petugas serta kelengkapan peralatan penunjang. yaitu bukti nyata dari kepedulian dan perhatian yang diberikan oleh penyedia jasa kepada konsumen. Pentingnya dimensi tangibles ini akan menumbuhkan image penyedia jasa terutama bagi konsumen baru.

b. Reliability / keandalan (kemampuan dan keandalan untuk menyediakan pelayanan yang terpercaya). Dimensi berkaitan dengan janji menyelesaikan sesuatu sepertidiinginkan, penanganan keluhan konsumen, kinerja pelayanan yang tepat, menyediakan pelayanan sesuai waktu yang dijanjikan serta tuntutan pada kesalahan pencatatan.

c. Responsiveness / ketanggapan (kesanggupan untuk membantu dan menyediakan pelayanan secara cepat dan tepat, serta tanggap terhadap keinginan konsumen). Dimensi responsiveness mencakup antara lain : pemberitahuan petugas kepada konsumen tentang pelayanan yang diberikan, pemberian pelayanan dengan cepat, kesediaan petugas memberi bantuan kepada konsumen serta petugas tidak pernah merasa sibuk untuk melayani permintaan konsumen.

d. Assurance / jaminan (kemampuan dan keramahan serta sopan sanun pegawai dalam meyakinkan kepercayaan konsumen). Assurance berkaitan dengan perilaku petugas yang tetap percaya diri pada konsumen, perasaan aman konsumen dan kemampuan (pengetahuan) petugas untuk menjawab pertanyaan konsumen. dan meyakinkan konsumen dalam pemberian jasa yang ditawarkan.

e. Emphaty / empati (sikap tegas tetapi penuh perhatian dari pegawai terhadap konsumen). Dimensi emphaty memuat antara lain : pemberian perhatian individual kepada konsumen, ketepatan waktu pelayanan bagi semua konsumen, peusahaan memiliki petugas yang memberikan perhatian khusus pada konsumen, pelayanan yang melekat di hati konsumen dan petugas yang memahami kebutuhan spesifik dari pelanggannya.

Berdasarkan Peraturan Mentri Pemberdayaan Aparatur negara dan Repormasi Birokrasi RI Nomor 16 tahun 2014 tentang pedoman surveikepuasan masyarakat terhadap penyelenggaraan pelayanan publik, terdapat 9 indikaor untuk mengukur Kepuasan Masyarakat yaitu :

1. Persyaratan

Persyaratan adalah syarat yang harus dipenuhi dalam pengurusan suatu jenis pelayanan, baik persyaratan teknis maupun administratif.

2. Prosedur 
Prosedur adalah tata cara pelayanan yang dibakukan bagi pemberi dan penerima pelayanan, termasuk pengaduan.

3. Waktu pelayanan

Waktu pelayanan adalah jangka waktu yang diperlukan untuk menyelesaikan seluruh proses pelayanan dari setiap jenis pelayanan.

4. Biaya/Tarif

Biaya/Tarif adalah ongkos yang dikenakan kepada penerima layanan dalam mengurus dan/atau memperoleh pelayanan dari penyelenggara yang besarnya ditetapkan berdasarkan kesepakatan antara penyelenggara dan masyarakat.

5. Produk Spesifikasi Jenis Pelayanan

Produk spesifikasi jenis pelayanan adalah hasil pelayanan yang diberikan dan diterima sesuai dengan ketentuan yang telah ditetapkan. Produk pelayanan ini merupakan hasil dari setiap spesifikasi jenis pelayanan.

6. Kompetensi Pelaksana

Kompetensi Pelaksana adalah kemampuan yang harus dimiliki oleh pelaksana meliputi pengetahuan, keahlian, keterampilan, dan pengalaman.

7. Perilaku Pelaksana

Perilaku Pelaksana adalah sikap petugas dalam memberikan pelayanan.

8. Maklumat Pelayanan

Maklumat Pelayanan adalah merupakan pernyataan kesanggupan dan kewajiban penyelenggara untuk melaksanakan pelayanan sesuai dengan standar pelayanan.

9. Penanganan Pengaduan, Saran dan Masukan

Penanganan pengaduan, saran dan masukan, adalah tata cara pelaksanaan penanganan pengaduan dan tindak lanjut.

\section{Metode Penelitian}

Penelitian ini dilakukan di kantor Kecamatan Banjarmasin Barat Kota Banjarmasin, Pada Bulan Januari 2020. Penelitian ini menggunakan pendekatan Kuantitatif deskriptif yaitu penelitian yang analisisnya lebih fokus pada data-data numerikal (angka) dengan menggunakan metode statistika. Desain penelitian ditetapkan dengan mengacu pada hipotesa yang telah dibangun. Pemilihan desain yang tepat sangat diperlukan untuk menjamin pembuktian hipotesa secara tepat. Penelitian ini melibatkan 40 orang sebagai responden. Responden yang ditemui adalah responden yang sedang melakukan dan atau mendapatkan berbagai macam pelayanan dari kantor kecamatan Banjarmasin Barat. Pengambilan sampel menggunakan tehnik Convenience sampling yaitu dengan cara mendatangi masyarakat yang sedang melakukan dan atau mendapatkan berbagai macam pelayanan dari kantor kecamatan di loket-loket pelayanan yang ada untuk diberikan kuesioner. Untuk menjadawab rumusan msalah pertama dan kedua peneliti menggunakan rumus Chi Square Goodnes Of Fit dan untuk menguji satu Variabel dan untuk menguji menjawab perbedaan seperti kriteria umur, jenis kelamin, tingkat pendidikan dan pekerjaan, dengan masalah kualitas pelayanan dan kepuasan masyarakat terhadap pelayanan publik menggunakan rumus perhitungan Chi Square Test Of Independence. Sedangkan untuk menjawab rumusan masalah ke 3 hubungan kualitas pelayan dengan kepuasan masyarakat menggunakan rumus Korelasi Person.

\section{Hasil Penelitian}

Profil responden berdasarkan Jenis kelamin responden terdapat laki laki 22 Orang dengan Persentase $55 \%$ dan Responden Perempuan 18 Orang dengan Persentase 45\%, berdasarkan tingkat Usia/atau Umur dari 17 - 29 tahun sebanyak 14 orang $35 \%$ sedangkan data terendah pada usia 56 - 65 tahun sebanyak 6 orang $15 \%$, karekteristik responden 
berdasarkan tingkat pendidikan SD 4 orang atau $10 \%$, SLTP 12 orang atau $30 \%$, SLTA 18 orang atau $45 \%$, dan Sarjana 6 orang atau $15 \%$, Karakteristik Pekerjaan, PNS 2 orang atau 5 $\%$, Tani 18 orang atau $45 \%$, Wiraswasta 17 orang atau $42.5 \%$ dan lainya 3 orang atau $7.5 \%$.

Lima dimensi Kualitas Pelayanan (Parasuraman dkk, 2010) berupa : Tangibles / Bukti langsung (kualitas pelayanan yang berupa sarana fisik perkantoran, komputerisasi administrasi, ruang tunggu dan tempat informasi) dengan 6 orang atau $15 \%$ dalam kategori cukup baik, 19 orang atau 47,5\% dalam kategori baik, dan 15 orang atau $37.5 \%$ dalam kategori sangat baik. Reliability / keandalan (kemampuan dan keandalan untuk menyediakan pelayanan yang terpercaya) dengan 8 orang atau 20\% dalam kategori cukup baik, 18 orang atau $45 \%$ dalam kategori baik, dan 14 orang atau 35\% dalam kategori sangat baik. Responsiveness / ketanggapan (kesanggupan untuk membantu dan menyediakan pelayanan secara cepat dan tepat, serta tanggap terhadap keinginan konsumen) 6 orang atau $15 \%$ dalam kategori cukup baik, 14 orang atau $35 \%$ dalam kategori baik, dan 20 orang atau $50 \%$ dalam kategori sangat baik. Assurance berkaitan dengan perilaku petugas yang tetap percaya diri pada konsumen, perasaan aman konsumen dan kemampuan (pengetahuan) petugas untuk menjawab pertanyaan konsumen. dan meyakinkan konsumen dalam pemberian jasa yang ditawarkan, dengan 1 orang atau 2.5\% dalam kategori kurang baik, 3 orang atau 7,5 $\%$ dalam kategori cukup baik, 17 orang atau 42,5\% dalam kategori baik, dan 19 orang atau $47.5 \%$ dalam kategori sangat baik. Emphaty / empati (sikap tegas tetapi penuh perhatian dari pegawai terhadap konsumen) 1 orang atau 2.5\% dalam kategori kurang baik , 6 orang atau $15 \%$ dalam kategori cukup baik, 14 orang atau $35 \%$ dalam kategori baik, dan 29 orang atau $72.5 \%$ dalam kategori sangat baik..

Kepuasan Masyarakat (PERMENPAN RI No 16/2014) ditinjau dari 9 indikator Kepuasan Masyrakat berupa; Persyaratan Pelayanan dengan 10 orang atau 25\% berpendapat cukup Puas, 12 orang atau $30 \%$ berpendapat puas, dan 18 orang atau 45\%. Prosedur Pelayanan dengan 8 orang atau 20\% berpendapat cukup puas, 14 orang atau 35\% berpendapat puas dan 18 orang atau $45 \%$ berpendapat sangat puas. Waktu pelayanan dengan 1 orang atau $2.5 \%$ berpendapat kurang puas, 6 orang atau $15 \%$ berpendapat cukup puas, 16 orang atau $40 \%$ bependapat puas, dan 16 orang berpendapat sangat puas. Biaya/Tarif dengan 1 orang atau $2.2 \%$ kurang puas, 9 orang atau $22.5 \%$ berpendapat cukup puas, 14 orang atau $35 \%$ berpendapat puas, dan 16 orang atau 40\%. Produk Spesifikasi Jenis Pelayanan dengan 3 atau $7.5 \%$ berpendapat cukup puas, 18 orang atau $45 \%$ berpendapat puas, dan 19 orang atau $47.5 \%$ berpendapat sangat puas. Kompetensi Pelaksana dengan 9 orang atau 22,5\% berpendapat cukup puas, 16 orang atau $40 \%$ berpendapat puas, dan 15 orang atau 37,5\% berpendapat sangat puas. Perilaku Pelaksana dengan 6 orang atau $15 \%$ termasuk dalam kategori cukup puas, 18 orang atau $45 \%$ dalam kategori puas, dan 16 orang atau 40\% dalam kategori sangat puas. Maklumat Pelayanan dengan 1 orang atau $2.5 \%$ persen berpendapat kurang puas, 19 orang atau $47.5 \%$ berpendapat puas, dan 20 orang atau $50 \%$ berpendapat sangat puas. Dan Penanganan Pengaduan, Saran dan Masukan dengan 7 orang atau $17.5 \%$ berpendapat cukup puas, 16 orang atau $40 \%$ berpendapat puas,dan 17 orang atau $42,5 \%$ berpendapat sangat puas.

\section{Kualitas Pelayanan Di Kantor Keacamatan Banjarmasin Barat Kota Banjarmasin}

Berdasarkan analisis penelitian yang dilakukan di Kecamatan Banjarmasin Barat Kota Banjarmasin diperoleh analisis perhitungan Chi squaere Goodness Of Fit terhadap perbedaan karakteristik responden kualitas pelayanan dapat dilihat bahwa Chi Square $x^{2}$ hitung yaitu 59,750, dan dengan nilai probalitasnya 0.000 , nilai tersebut kemudian dibandingkan dengan $x^{2}$ tabel pada df 6 dengan huruf signifikan 0,05 yaitu 12,592, Jadi $\mathrm{x}^{2}$ 
hitung 59,750 > $\mathrm{x}^{2}$ 12,592 maka Ho ditolak, Dapat diartikan bahwa kualitas pelayanan di Kantor Kecamatan Banjarmasin Barat Kota Banjarmasin tidak tersebar di semua tingkat kategori.

Hasil analisis perhitungan Chi Square Test terhadap perbedaan karakteristik Jenis Kelamin dapat dilihat bahwa Chi Square $x^{2} 0,636$, dan nilai probabilitas 0,728 . Nilai tersebut kemudian dibandingkan dengan $X^{2}$ tabel df 2 dengan taraf signifikan 0,05 yaitu 5,991 jadi $\mathrm{x}^{2}$ hitung $0636<x^{2} 55,991$ maka Ho diterima. Dapat diartikan bahwa tidak terdapat perbedaan karakteristik Jenis kelamin dengan persepsi masyarakat terhadap kualitas pelayanan di kantor kecamatan Banjarmasin Barat dapat dikatakan bahwa pelayanan yang diberikan oleh Kecamatan Banjarmasin Barat dilaksanakan dengan baik tidak memandang jenis kelamin laki-laki atau perempuan.

Hasil analisis Chi Square Test terhadap perbedaan karakteristik Umur diperoleh hasil hitung Chi Square $\mathrm{x}^{2}$ yaitu 10,386,dan nilai probabilitasnya 0,109, nilai tersebut kemudian dibandingkan dengan $\mathrm{x}^{2}$ tabel pada df 6 dengan taraf signifikan 0,05 yaitu 12,592. Oleh karena nilai 10,386 < $\mathrm{x}^{2}$ 12,592 maka Ho diterima. Hal ini dapat diartikan bahwa tidak terdapat perbedaan antara karakteristik umur dengan persepsi masyarakat terhadap kualitas pelayanan di kantor kecamatan Banjarmasin Barat. maka dapat dikatakan bahwa pelayanan yang diberikan oleh Kecamatan Banjarmasin Barat Kota Banjarmasin dilaksanakan tanpa memandang tingkatan usia masyarakat.

Hasil analisis Chi Square Test terhadap perbedaan karakteristik Tingkat Pendidikan diperoleh hasil hitung Chi Square $\mathrm{x}^{2}$ yaitu 10,913, dan nilai probabilitasnya 0,091, nilai tersebut kemudian dibandingkan dengan $\mathrm{x}^{2}$ tabel pada df 6 dengan taraf signifikan 0,05 yaitu 12,592. Oleh karena itu $x^{2} 10,913<x^{2}$ tabel 12,592 maka hasil Ho diterima. Dapat diartikan bahwa tidak terdapat perbedaan antara tingkat pendidikan dengan persepsi masyarakat terhadap kualitas pelayanan Di Kantor Kecamatan Banjarmasin Barat. Maka dapat di katakan bahwa pelayanan yang dilakukan tidak memandang tingkat pendidikan seseorang dalam mendapatkan pelayanan.

Hasil analisis perhitungan Chi Square Test terhadap Karaktristik Pekerjaan diperoleh hasil Chi Square $\mathrm{x}^{2}$ hitung yaitu 4,993, dan nilai probabilitasnya 0,545 , nilai tersebut kemudian dibandingkan dengan $\mathrm{x}^{2}$ label pada df 6 denagn taraf signifikan 0.05 yaitu 12,592. Oleh karena itu $x^{2} 4,993<x^{2} 12,592$ maka Ho diterima. Dapat diartikan bahwa tidak terdapat perbedaan antara jenis pekerjaan dengan persepsi masyarakat terhadap kualitas pelayanan di kantor kecamatan Banjarmasin Barat. Maka dapat di katakan bahwa pelayanan yang dilakukan tidak berdasarkan pekerjaannya dalam mendapatkan pelayanan.

\section{Kepuasan Masyarakat Di Kantor Keacamatan Banjarmasin Barat Kota Banjarmasin}

Berdasarkan hasil analisis perhitungan Chi squaere Goodness Of Fit diperoleh hasil Chi Square $x^{2}$ hitung yaitu 19,000, dan dengan nilai probalitasnya 0,025 , nilai tersebut kemudian dibandingkan dengan $x^{2}$ tabel pada $d f 9$ dengan huruf signifikan 0,05 yaitu 16,919, Jadi $\mathrm{x}^{2}$ hitung 19,000 > $\mathrm{x}^{2}$ tabel 16,919 maka Ho ditolak, Dapat diartikan bahwa Kepuasan Masyarakat yang diberikan di Kantor Kecamatan Banjarmasin Barat Kota Banjarmasin tidak tersebar di semua tingkat kategori. 
Hasil analisis perhitungan Chi Square Test terhadap perbedaan karakteristik Jenis Kelamin dapat di peroleh hasil Chi Square $x^{2} 11,332$, dan nilai probabilitas 0,003 . Nilai tersebut kemudian dibandingkan dengan $\mathrm{x}^{2}$ tabel df 2 dengan taraf signifikan 0,05 yaitu 5,991 jadi, $\mathrm{x}^{2}$ nilai hitung 11,332 > $\mathrm{x}^{2}$ tabel 5,991 maka Ho ditolak. Dapat diartikan bahwa terdapat perbedaan karakteristik Jenis kelamin dengan persepsi masyarakat terhadap kepuasan masyarakat di Kantor Kecamatan Banjarmasin Barat dapat dikatakan bahwa kepuasan masyarakat yang diberikan oleh Kecamatan Banjarmasin Barat Kota Banjarmasin bahwa terdapat perbedaan tingkat kepuasan antara jenis kelamin laki-laki dan perempuan .

Hasil analisis Chi Square Test terhadap perbedaan karakterisik Umur diperoleh hasil hitung Chi Square x2 yaitu 2,303, dan nilai probabilitasnya 0,890, nilai tersebut kemudian dibandingkan dengan $\mathrm{x} 2$ tabel pada df 6 dengan taraf signifikan 0,05 yaitu 12,592. Oleh karena nilai 2,303 < $\mathrm{x}^{2}$ 12,592 maka Ho diterima. Dapat diartikan bahwa tidak terdapat perbedaan antara karakteristik umur dengan persepsi masyarakat terhadap kualitas pelayanan di kantor kecamatan Banjarmasin Barat. Maka dapat dikatakan bahwa pelayanan yang diberikan oleh kecamatan Banjarmasin Barat dilaksanakan dengan baik pelayanan tidak memandang usia masyarakatnya.

Hasil analisis Chi Square Test terhadap perbedaan karakteristik tingkat pendidikan hasil hitung Chi Square $x^{2}$ yaitu 11,746 , dan nilai probabilitasnya 0,068 , nilai tersebut kemudian dibandingkan dengan $\mathrm{x}^{2}$ tabel pada df 6 dengan taraf signifikan 0,05 yaitu 12,592, oleh karena nilai $\mathrm{x}^{2}$ hitung $11,746<\mathrm{x}^{2} 12,592$ maka Ho diterima. Dapat diartikan bahwa tidak terdapat perbedaan antara tingkat pendidikan dengan persepsi masyarakat terhadap kepuasan masyarakat Di Kantor Kecamatan Banjarmasin Barat. Maka dapat di katakan bahwa pelayanan yang dilakukan tidak memandang tingkat pendidikan seseorang dalam mendapatkan pelayanan.

Hasil analisis perhitungan Chi Square Test terhadap perbedaan karakteristik Pekerjaan di peroleh hasil Chi Square $\mathrm{x}^{2}$ hitung yaitu : 7,175, dan nilai probabilitasnya 0,305 , nilai tersebut kemudian dibandingkan dengan $\mathrm{x}^{2}$ label pada df 6 dengan taraf signifikan 0.05 yaitu 12,592, Oleh karena Nilai $x^{2}$ hitung 7,175 $<x^{2} 12,592$ maka Ho diterima. Dapat diartikan bahwa tidak terdapat perbedaan antara jenis pekerjaan dengan persepsi masyarakat terhadap kepuasan masyarakat di Kantor Kecamatan Banjarmasin Barat. Maka dapat dikatakan bahawa pelayanan yang dilakukan tidak memandang tingkat pendidikan seseorang dalam mendapatkan pelayanan.

\section{Hubungan Antara Kualitas Pelayanan Dengan Tingkat Kepuasan Masyarakat di Kantor Kecamatan Banjarmasin Barat Kota Banjarmasin}

Berdasarkan hasil analisis hubungan Kualitas Pelayanan dengan tingkat Kepuasan Masyarakat di wilayah Kecamatan Banjarmasin Barat Kota Banjarmasin yang telah mendapatkan layanan yang bersifat kebutuhan kependudukan. Diperoleh hasil korelasi person 0,205 dan hasil signifikasinya 0,204. untuk besaran angka korelasi menunjukan bahwa kuaitas pelayanan dengan kepuasan masyarakat menunjukan angka kategori korelasi lemah, dari hasil korelasi tersebut menunjukan bahwa $X$ hitung denagan nilai 0,204 > 0,05 maka hasil hipotesis ditolak. 
Dapat dikatakan bahwa Terdapat hubungan antara kualitas pelayanan dengan kepuasan masyarakat Di Kantor Kecamatan Banjarmasin Barat Kota Banjarmasin berdasarkan data yang di peroleh dari masyarakat .

\section{Kesimpulan dan Keterbatasan Penelitian}

Kualitas Pelayanan Di Kantor Kecamatan Banjarmasin Barat tidak Tersebar Disemua tingkat kategori Dari hasil hitungan Chi squaere Goodness Of Fit terhadap perbedaan karakteristik responden kualitas pelayanan dapat dilihat bahwa Chi Square $x^{2}$ hitung yaitu 59,750, dan dengan nilai probalitasnya 0.000 dengan perbandingan tabel hitung df 6 dengan taraf signifikasi 5\% yaitu 12,592, Jadi $\mathrm{x}^{2}$ hitung 59,750 > $\mathrm{x}^{2}$ 12,592 maka Ho ditolak. Perbedaan karakteristik perbedaan Jenis Kelamin, pendidikan, dan Pekerjaan terhadap Kualitas Pelayanan Di Kantor Kecamatan Banjarmasin Barat Kota Banjarmasin yaitu tidak terdapat perbedaan karakteristik dengan persepsi masyarakat terhadap Kualitas Pelayanan Yang diberikan. Dengan niai perbedaan karakteristik Jenis Kelamin 0,728, Umur 0,109, Tingkat Pendidikan 0,091, dan nilai Pekerjaan 0,545.

Kepuasan Masyarakat Di kantor Kecamatan Banjarmasin Barat tidak Tersebar Disemua tingkat kategori Dari hasil hitungan Chi squaere Goodness Of Fit terhadap perbedaan karakteristik responden kepuanan Masyarakat dapat dilihat bahwa Chi Square $x^{2}$ hitung yaitu 19,000, dan dengan nilai tingkat kategori yaitu 0.025. Dengan perbandingan tabel hitung df 9 dengan taraf signifikasi $5 \%$ yaitu 19,000, Jadi $x^{2}$ hitung 19,000 > $x^{2} 16,919$ maka Ho ditolak. Perbedaan karakteristik Jenis Kelamin, Umur, Tingkat pendidikan, dan Pekerjaan terhadap kepuasan masyrakat Di Kantor Kecamatan Banjarmasin Barat, terdapat perbedaan karakteristik jenis kelamin antara karakteristik Umur, Tingkat Pendidikan, dan Pekerjaan dengan persepsi masyarakat terhadap kepuasan masyarakat dengan nilai Jenis Kelamin sebesar 0,003, dengan Kategori Umur 0,890, Tingkat Pendidikan 0,068, dan nilai Pekerjaan 0,305.

Hubungan Kualitas Pelayanan dengan tingkat kepuasan masyarakat di wilayah Kecamatan Banjarmasin Barat Kota Banjarmasinyang telah mendapatkan layanan yang bersifat kebutuhan kependudukan. Dengan hasil korelasi person 0,205 dan hasil signifikasinya 0,204 . untuk besaran angka korelasi menunjukan bahwa kuaitas pelayanan dengan kepuasan masyarakat menunjukan angka kategori korelasi lemah,dari hasil korelasi tersebut menunjukan bahwa $X$ hitung denagan nilai 0,204 > 0,05 maka hasil hipotesis ditolak. Disimpulkan bahwa Terdapat hubungan antara kualitas pelayanan dengan kepuasan masyarakat. Disimpulkan bahwa Terdapat hubungan antara kualitas pelayanan dengan kepuasan masyarakat.

Berdasarkan hasil penelitian ini, dapat dikemukakan beberapa saran sebagai berikut :

1. Salah satu cara meningkatkan Kualitas Pelayanan adalah menciptakan Kepuasan bisa melalui peningkatan kualitas pelayanan itu sendiri baik berupa hasil pelayanan atau rasa senang terhadap pelayanan. Berdasarkan hasil analisis Kualitas Pelayanan yang dilakukan Di Kecamatan Banjarmasin Barat Kota Banjarmasin masuk dalam kategori sangat baik, hal ini dapat diartiakan bahwa Kualitas Pelayanan di Kantor Kecamatan Banjarmasin Barat Kota Banjarmasin Sudah maksimal dan Bagus namun bisa diupayakan lebih maksimal lagi karena masih adanya yang memberikan pendapat yang kurang baik. 
2. Peningkatan Kepuasan Masyarakat dapat dilihat dari banyaknya masyrakat memberikan respon puas terhadap suatu pelayanan. Berdasarkan hasil analisis Kepuasan Masyarakat yang dilakukan Di Kecamatan Banjarmasin Barat Kota Banjarmasin masuk dalam kategori baik, hal ini dapat diartiakan bahwa Kepuasan Masyarakat di Kantor Kecamatan Banjarmasin Barat Kota Banjarmasin Sudah maksimal, namun dalam upaya Meningkatkan Kualiatas Pelayanan harus tetap dilakukan sehingga dapat memberikan pelayanan yang memuaskan demi kebutuhan Masyarakat.

\section{DAFTAR PUSTAKA}

Aswin, A. (2015). Studi Tentang Pelayanan Publik Pada Kantor UPTD Dinas Pendapatan Daerah Provinsi Kalimantan Timur di Samarinda. Jurnal Magister Ilmu Administrasi Negara.

Hardiansyah. 2017 . Manajemen Pelayanan Dan Pembangunan Organisasi Publik. Yogyakarta. Gava Media

Kothler, Philip. 2012. Managemen Pemasaran. Edisi ke-12. Jakarta : Indeks

Kothler, Philip and Kevin Lane Keller.2012. Marketing Management. Edisi 14. Boston :

Pearson Education

Mauluddin Hanif. 2010. Marketing Research : Panduan Bagi Manager, Pemimpin

Perusahaan Organisasi. Jakarta : Elex Media Komputindo

Muhammad Rhida Rachmatullah, (2019, 27 Februari). Pentingnya Standar Pelayanan Publik.

Dikutif 2 Maret 2020 : https://ombudsman.go.id/artikel/r/artikel--pentingnya-standar-

pelayanan-publik

Nina Rahmayanty, Manajemen Pelayanan Prima, (Yogyakarta: PT Graha Ilmu, 2013

Sugiono 2016. Metode Penelitian Pendidikan Pendekatan Kuantitatif, Kualitatif Dan R\& D.

Bandung : Alfabeta

Parasuraman, A. Dkk. (2010) Serqual : A Multiple-Item Scale For Measuring Consumer

Perception Of Service Quality. Journal Of Retailing, Vol. 64. Pp 12-40

Peraturan Menteri Pendayagunaan Aparatur Negara Dan Reformasi Birograsi

(PERMENPAN RB) NOMOR 16 tahun 2014

Undang-Undang Nomor 25 Tahun 2009 tentang Pelayanan Publik. Undang Undang no 23

tahun 2014 tentang pemerintah Daerah

Undang Undang No 23 tahun 2014 tentang pemerintah Daerah

Zeithaml, Valarie A. Mary Jo Bitner dan Dwayne D. Gremler, 2009. “Services Marketing-

Integrating Customer Focus Across the Firm 5th Edition" New York : Mc Graw-Hill. 